\title{
A COMPARATIVE STUDY OF PALONOSETRON AND PALONOSETRON WITH DEXAMETHASONE FOR PROPHYLAXIS OF POSTOPERATIVE NAUSEA AND VOMITING IN LAPAROSCOPIC CHOLECYSTECTOMY UNDER GENERAL ANAESTHESIA
}

\author{
Sinam Neetu Devi ${ }^{1}$, Rakesh Nongthombam², Takhelmayum Hemjit Singh ${ }^{3}$, Lairenlakpam Deban Singh ${ }^{4}$,Manichandra Sinam ${ }^{5}$, \\ Chingambam Rabindra Singh 6
}

1 Postgraduate Student, Department of Anaesthesiology and Critical Care, RIMS.

${ }^{2}$ Assistant Professor, Department of Anaesthesiology and Critical Care, JNIMS.

${ }^{3}$ Assistant Professor, Department of Anaesthesiology and Critical Care, RIMS.

${ }^{4}$ Professor and HOD, Department of Anaesthesiology and Critical Care, RIMS.

${ }_{5}^{5}$ Senior Resident, Department of Anaesthesiology and Critical Care, RIMS.

${ }^{6}$ Postgraduate Student, Department of Anaesthesiology and Critical Care, RIMS.

\section{ABSTRACT}

\section{BACKGROUND}

Postoperative nausea and vomiting is the most common and unpleasant event following laparoscopic cholecystectomy often involving multifactorial pathways and receptors. Combination prophylaxis acting through different mechanisms has been shown to be superior to the use of a single agent in prevention of PONV. We designed this study to find out and compare the efficacy of preoperative palonosetron and palonosetron with dexamethasone for the prevention of Postoperative Nausea and Vomiting (PONV) following elective laparoscopic cholecystectomy under general anaesthesia.

\section{MATERIALS AND METHODS}

A total of 100 patients of American Society of Anaesthesiologists (ASA) physical status I and II patients, aged 18 to 65 years, weighing 40 - $75 \mathrm{~kg}$ scheduled for elective laparoscopic cholecystectomy were enrolled and divided into palonosetron (P) group (n $=50)$ and Palonosetron Dexamethasone (PD) Group $(\mathrm{n}=50)$. Group P patients received Inj. palonosetron $0.075 \mathrm{mg}$ IV and Group PD patients received a combination of Inj. palonosetron $0.075 \mathrm{mg}$ with Inj. dexamethasone $8 \mathrm{mg}$ IV in a randomised and doubleblinded approach. Nausea, retching, vomiting, complete response, rescue antiemetic and any side effects were evaluated postoperatively. Statistical Package for Social Sciences (SPSS Inc. Chicago IL, USA) windows based version 21.0 was used for analysis of data. Comparisons between groups were performed by using the independent t-test and Chi Square test. P $<0.05$ was considered to be statistically significant.

\section{RESULTS}

The incidence of complete response was higher in PD Group than P Group during 0 - 2 hrs. (86\% vs $70 \%)(\mathrm{P}=0.045$ and 0 - 48 hrs. $(86 \%$ vs $70 \%)(\mathrm{P}=0.045)$ postoperative periods. The use of rescue antiemetic was lower in PD Group (14\% vs $30 \%)(\mathrm{P}=0.045)$ during 0 - 2 hrs. and 0 - 48 hrs. (14\% vs 30\%) ( $\mathrm{P}=0.045)$.

\section{CONCLUSION}

Combination prophylaxis of intravenous palonosetron $0.075 \mathrm{mg}$ and dexamethasone $8 \mathrm{mg}$ is more effective than palonosetron in the prevention of PONV in patients undergoing laparoscopic cholecystectomy under general anaesthesia without any major adverse effects.

\section{KEYWORDS}

Postoperative Nausea and Vomiting (PONV), Palonosetron, Dexamethasone, Laparoscopic Cholecystectomy, General Anaesthesia.

HOW TO CITE THIS ARTICLE: Devi SN, Nongthombam R, Singh TH, et al. A comparative study of palonosetron and palonosetron with dexamethasone for prophylaxis of postoperative nausea and vomiting in laparoscopic cholecystectomy under general anaesthesia. J. Evolution Med. Dent. Sci. 2017;6(18):1404-1408, DOI: 10.14260/Jemds/2017/307

\section{BACKGROUND}

Postoperative Nausea and Vomiting (PONV) is a well-known unpleasant and distressing adverse effect of laparoscopic surgeries and chemotherapy induced, experienced by the patients and its incidence ranges from $53-72 \%{ }^{1}$

Financial or Other, Competing Interest: None.

Submission 24-01-2017, Peer Review 18-01-2017,

Acceptance 23-02-2017, Published 02-03-2017.

Corresponding Author:

Dr. Rakesh Nongthombam,

Luwangsangbam Mamang Leikai,

Near Essar Oil Pump,

Mantripukhri-795002

Imphal, Manipur.

E-mail: kanglanong@gmail.com

DOI: $10.14260 /$ jemds $/ 2017 / 307$

\section{(c) $($ ) $\ominus$}

Laparoscopic cholecystectomy is now the treatment of choice for symptomatic cholelithiasis due to its reduction in postoperative morbidity and shorter convalescence. But the incidence of PONV and postoperative pain is increased due to the effect of residual stretching and irritation of the peritoneum. ${ }^{2,3}$ Pharmacological therapy consists of anticholinergics (e.g. Scopolamine), butyrophenone (e.g. Droperidol), benzamide (eg. Metoclopramide) and 5-HT3 inhibitors (e.g. Ondansetron) are found to be beneficial for PONV, though not up to the acceptable limit. 4,5 Some of the non-traditional agents like propofol, dexamethasone have also been used as a prophylaxis of PONV. Multiple studies are being conducted to find an amicable solution to this problem. So understanding its neurophysiology, sorting out the risk factors and cumulating knowledge about the various antiemetics available is the need of the hour. Currently, 
serotonin receptor antagonists have been proven as a valuable addition to the armamentarium against managing PONV. Palonosetron is a second generation serotonin receptor antagonist, which has been shown to be superior to other drugs in its class for the prevention of acute, delayed and chemotherapy induced nausea and vomiting due to its allosteric binding to $5-\mathrm{HT}_{3}$ receptor and longer halflife. $6,7,8,9,10,11$ The cause of PONV is very often multifactorial and involves multiple pathways and receptors. Combination therapy has been shown to be superior to the use of a single agent. Dexamethasone is a common component of the combination therapy, whose antiemetic effect has also been proven by various studies conducted.12,13,14,15,16,17 So keeping in mind the recently concluded fact that a multimodal management and routine antiemetic prophylaxis results in an increased level of patient's satisfaction than symptomatic treatment in high risk population, which is supported by the numerous studies done on this topic, $18,19,20$ we would compare the antiemetic effect of palonosetron (monotherapy) and palonosetron with dexamethasone (combination therapy) in the management of postoperative nausea and vomiting following laparoscopic cholecystectomy under general anaesthesia in our study.

\section{MATERIALS AND METHODS}

A prospective, randomised, double-blinded study was conducted in a Tertiary Care Centre, Imphal, Manipur, over a period of two years between September 2014 and August 2016. After obtaining approval from the Institutional Ethics Committee and written informed consent from 100 participating patients of either sex with American Society of Anaesthesiologists (ASA) physical status I and II patients, aged 18 to 65 years, weighing $40-75 \mathrm{~kg}$, scheduled for elective laparoscopic cholecystectomy under general anaesthesia were randomly allocated into two groups of 50 patients each, either to receive Inj. palonosetron (Group P) or Inj. palonosetron with dexamethasone (Group PD). Patients who were clinically ill with intestinal, liver or renal disease, pregnant or menstruating, having psychiatric disorder, history of motion sickness and PONV, taken antiemetic drugs 24 hrs. preoperatively, received cancer chemotherapy within past four weeks and emetogenic radiotherapy within past 8 weeks, etc. were excluded from the study. Hypersensitivity to 5-HT3 antagonists and dexamethasone, and patients on chronic steroid therapy or immunocompromised were also excluded from the study.

50 patients for each group was recruited based on study conducted by Bhattarcharjee D $\mathrm{P}^{21}$ et al and assuming complete response of $67 \%$ and $90 \%$ in palonosetron and palonosetron with dexamethasone in $24 \mathrm{hrs}$. to $48 \mathrm{hrs}$. Primary outcome of the study included parameters like nausea, vomiting, complete response, rescue antiemetic and any side effects.

Pre-anaesthetic checkup was done on patients scheduled for elective laparoscopic cholecystectomy under general anaesthesia. All patients were advised overnight fasting and premedicated with tab. Alprazolam $0.5 \mathrm{mg}$ and cap. Ranitidine $50 \mathrm{mg}$ orally night before the surgery.

Injection ranitidine $150 \mathrm{mg}$ and Inj. glycopyrrolate $0.2 \mathrm{mg}$ were given by Intravenous (IV) route, before start of the anaesthetic procedure. Randomisation was done by a computer-generated table of random numbers. The anaesthesiologist blinded to the study prepared the study drugs in identical $5 \mathrm{~mL}$ syringes containing either Inj. palonosetron $0.075 \mathrm{mg}$ or Inj. palonosetron $0.075 \mathrm{mg}$ and Inj. dexamethasone $8 \mathrm{mg}$ (total volume of $5 \mathrm{~mL}$ made with normal saline to avoid visual bias) prior to induction. Group P patients received Inj. palonosetron $0.075 \mathrm{mg}$ and Group PD received a combination of Inj. palonosetron $0.075 \mathrm{mg}$ with Inj. dexamethasone $8 \mathrm{mg}$. The study drugs were administered slow IV just before induction of anaesthesia.

A uniform anaesthetic technique was maintained in all the two groups. The patients were pre-oxygenated with 100\% oxygen for 3 mins. and induced with IV $2.5 \%$ Inj. thiopentone $5 \mathrm{mg} / \mathrm{kg}$ followed by IV Inj. rocuronium $(0.6 \mathrm{mg} / \mathrm{kg}$ body weight) and endotracheal intubation with appropriate size endotracheal tube performed. The anaesthesia was maintained with inhaling nitrous oxide, isoflurane in oxygen and intermittent bolus doses of Inj. rocuronium bromide $(0.1$ - $0.2 \mathrm{mg} / \mathrm{kg}$ body weight). Inj. diclofenac $75 \mathrm{mg}$ IM and Inj. tramadol $2 \mathrm{mg} / \mathrm{kg}$ bodyweight IV was given as analgesia.

Intraoperatively, heart rate, Non-Invasive Blood Pressure (NIBP), Electrocardiography (ECG), Oxygen Saturation (Sp02) and End-Tidal Carbon Dioxide (ETCO2) was monitored. Ventilation was maintained with ETCO2 at 30 - 35 $\mathrm{mmHg}$ (side stream) and intra-abdominal pressure below 15 $\mathrm{mmHg}$. At the end of the operation, residual neuromuscular blockade was reversed with Inj. neostigmine $0.05 \mathrm{mg} / \mathrm{kg}$ IV and glycopyrrolate $0.01 \mathrm{mg} / \mathrm{kg}$ IV. Extubation was done after suction of the oropharynx and adequate recovery, judged on a clinical basis.

After the surgery, data was collected up to $48 \mathrm{hrs}$. postoperatively with the initial $0-2 \mathrm{hrs}$. in the Post Anaesthesia Care Unit (PACU) and thereafter (2 - $48 \mathrm{hrs}$.) in the ward. All patients were evaluated for PONV, rescue antiemetic and adverse effects of drugs for the first $48 \mathrm{hrs}$. after anaesthesia. Inj. metoclopramide $10 \mathrm{mg}$ IV was given as rescue antiemetic to patient on request or when vomiting occurs. In order to minimise suffering from post-operative nausea and vomiting, patients were educated to inform and request treatment when nausea and vomiting occur, after conclusion of the surgery.

The data collected were entered on a computer and analysed with SPSS for Windows (SPSS Inc. Chicago, IL, USA) version 21.0 and was presented in a tabulated manner. Comparisons between groups were performed by using the independent t-test and Chi Square test whichever were appropriate and $\mathrm{P}<0.05$ was considered to be significant.

\section{RESULTS}

One hundred patients completed the study protocol. The demographic parameters such as age, sex, body weight, height and ASA (as shown in Table 1) were comparable in the two groups and will not influence the study results. Also, the duration of anaesthesia and surgery were also similar in the two groups. There were no comorbidities associated with all the enrolled patients.

The comparison of incidence of Post-Operative Nausea and Vomiting (PONV), complete response and rescue antiemetic during 0 - 2 hrs., 2 - 48 hrs. and 0 - 48 hrs. are shown in Table 2. The incidence was comparatively less in the Group PD than Group P during 0 - 2 hrs. and statistically significant $(\mathrm{P}<0.05)$; but during the $2-48 \mathrm{hrs}$. the incidence were comparable and not significant $(P>0.05)$. However, 
during the overall 0 - $48 \mathrm{hrs}$., the incidence was more in the Group $\mathrm{P}$ and statistically significant $(\mathrm{P}<0.05)$.

The incidence of adverse effects, although more with the Group P as shown in Table 3 were comparable with Group PD and statistically significant $(\mathrm{P}<0.05)$.

\begin{tabular}{|c|c|c|c|}
\hline & $\begin{array}{c}\text { Grp P } \\
(n=50)\end{array}$ & $\begin{array}{l}\text { Grp PD } \\
(n=50)\end{array}$ & $\begin{array}{c}P \\
\text { value }\end{array}$ \\
\hline Age (years) & $41.56 \pm 11.21$ & $39.28 \pm 11.72$ & 0.472 \\
\hline Sex (M:F) & $11: 39$ & $11: 39$ & 0.595 \\
\hline Body weight (kg) & $59.10 \pm 7.92$ & $60.46 \pm 10.10$ & 0.209 \\
\hline Height $(\mathrm{cm})$ & $161.10 \pm 2.84$ & $160.98 \pm 2.54$ & 0.432 \\
\hline ASA (I:II) & $45: 5$ & $49: 1$ & 0.102 \\
\hline $\begin{array}{c}\text { Duration of } \\
\text { Surgery (mins.) }\end{array}$ & $51.30 \pm 13.62$ & $53.30 \pm 21.32$ & 0.434 \\
\hline $\begin{array}{l}\text { Duration of } \\
\text { Anaesthesia } \\
\text { (mins.) }\end{array}$ & $57.60 \pm 14.61$ & $58.80 \pm 15.21$ & 0.875 \\
\hline $\begin{array}{l}\text { Presence : } \\
\text { Absence of } \\
\text { Comorbidities }\end{array}$ & $5: 45$ & $1: 49$ & 0.102 \\
\hline \multicolumn{4}{|c|}{$\begin{array}{l}\text { Table 1. Distribution of Demographic Profiles, ASA } \\
\text { Physical Status, Duration of Surgery, Duration of } \\
\text { Anaesthesia, Presence and Absence of Comorbidities }\end{array}$} \\
\hline
\end{tabular}

$(\mathrm{P}<0.05$ is significant)

\begin{tabular}{|c|c|c|c|}
\hline $\begin{array}{c}\text { Duration } \\
\text { (Hours) }\end{array}$ & $\begin{array}{c}\text { Grp P } \\
(n=50)\end{array}$ & $\begin{array}{l}\text { Grp PD } \\
(n=50)\end{array}$ & $P$ value \\
\hline \multicolumn{4}{|l|}{$0-2$} \\
\hline Nausea & $15(30 \%)$ & $7(14 \%)$ & $0.045^{*}$ \\
\hline Retching & $12(24 \%)$ & $4(8 \%)$ & $0.027^{*}$ \\
\hline Vomiting & $12(24 \%)$ & $5(10 \%)$ & 0.054 \\
\hline Complete Response & $35(70 \%)$ & $43(86 \%)$ & $0.045^{*}$ \\
\hline Rescue Antiemetic & $15(30 \%)$ & $7(14 \%)$ & 0.045 \\
\hline \multicolumn{4}{|l|}{$2-48$} \\
\hline Nausea & $5(10 \%)$ & $3(6 \%)$ & 0.357 \\
\hline Retching & $3(6 \%)$ & $1(2 \%)$ & 0.309 \\
\hline Vomiting & $3(6 \%)$ & $1(2 \%)$ & 0.309 \\
\hline Complete Response & $45(90 \%)$ & 47 (94\%) & 0.357 \\
\hline Rescue Antiemetic & $5(10 \%)$ & $3(6 \%)$ & 0.357 \\
\hline \multicolumn{4}{|l|}{$0-48$} \\
\hline Nausea & $15(30 \%)$ & $7(14 \%)$ & $0.045^{*}$ \\
\hline Retching & $12(24 \%)$ & $4(8 \%)$ & $0.027^{*}$ \\
\hline Vomiting & $12(24 \%)$ & $5(10 \%)$ & 0.054 \\
\hline Complete Response & $35(70 \%)$ & $43(86 \%)$ & $0.045^{*}$ \\
\hline Rescue Antiemetic & $15(30 \%)$ & $7(14 \%)$ & $0.045^{*}$ \\
\hline
\end{tabular}

Table 2. Incidence of Post-Operative Nausea and Vomiting, Complete Response and Rescue Antiemetic during 0 - 2 Hours, 2 - 48 Hours and 0 - 48 Hours

$\left(^{*}=\right.$ significant $\left.\{\mathrm{P}<0.05\}\right)$

\begin{tabular}{|c|c|c|c|}
\hline & Grp P & Grp PD & P value \\
\hline Headache & $7(14 \%)$ & $1(2 \%)$ & 0.056 \\
\hline Dizziness & $4(8 \%)$ & $2(4 \%)$ & 0.339 \\
\hline Constipation & $1(2 \%)$ & - & 0.500 \\
\hline Muscle Pain & $1(2 \%)$ & - & 0.500 \\
\hline Others & - & - & - \\
\hline Table 3. Distribution of Patients with Respect to the \\
Incidence of Adverse Effect during 0 - 48 Hours Post- \\
Operative Periods \\
\hline
\end{tabular}

( $\mathrm{P}<0.05$ is significant $)$

\section{DISCUSSION}

Palonosetron is a second generation $5-\mathrm{HT}_{3}$ receptor antagonist superior to other $5-\mathrm{HT}_{3}$ antagonists due to the allosteric binding and positive cooperativity leading to a longer half-life (37 hrs.).7,8 However, it is associated with headache, dizziness and constipation. ${ }^{10}$ In a study conducted by Bhatacharjee DP et al, ${ }^{21}$ palonosetron was proved to be an effective antiemetic than granisetron for prevention of postoperative nausea and vomiting. Similarly, Park SK et al ${ }^{22}$ also observed that the incidence of postoperative nausea and vomiting was lesser in palonosetron than ondansetron group, thereby proving the fact that palonosetron is superior among the $5 \mathrm{HT}_{3}$ antagonist.

Dexamethasone, a long-acting glucocorticoid and potent synthetic analog of cortisol acts at different site, makes the antiemetic property more effective as a combination therapy. Though not known exactly, it has been suggested that its antiemetic action has been exerted through activation of the glucocorticoid receptors in bilateral nuclei tractus solitarii in medulla. ${ }^{12}$ Wang J J et al ${ }^{14}$ studied the role of prophylactic dexamethasone and found significant reduction in the incidence of nausea and vomiting (23\% versus $63 \%$ in the saline group, $p=0.001$ ) after laparoscopic cholecystectomy.

There were some debates in relation to the dose of palonosetron $^{18}$ and dexamethasone 23 as the prophylaxis of PONV during our study. We considered using the dose of $0.075 \mathrm{mg}$ palonosetron and $8 \mathrm{mg}$ dexamethasone, as it was used most frequently in various previous studies. ${ }^{19,24}$

In our study patient's age, weight, height, gender, duration of surgery and duration of anaesthesia in both the groups were comparable. This has been able to reduce the preoperative risk factors bias among the study group.

The incidence of nausea, retching and vomiting was 14\%, $8 \%$ and $10 \%$ respectively among PD Group during the first 0 2 hrs. observation, whereas it was $30 \%, 24 \%$ and $24 \%$ respectively in the $\mathrm{P}$ Group which is statistically significant (P $<0.05$ ). These findings are comparable to the studies of Park J $\mathrm{W}$ et $\mathrm{al},{ }^{20}$ where they reported the incidence of nausea and vomiting was $7.3 \%$ and $0 \%$ respectively during the first $0-2$ hrs. among P Group and $11.6 \%$ and $0 \%$ respectively among PD Group. Bala I et $\mathrm{al}^{19}$ observed the incidence of nausea and vomiting was $40.4 \%$ and $11.9 \%$ respectively during the first 0 - 2 hrs. in palonosetron group, whereas it was $14.2 \%$ and $4.8 \%$ respectively in the palanosetron-dexamethasone group. However, Ghosh S et $\mathrm{al}^{24}$ reported that none of their patients had nausea and vomiting during the first $0-2 \mathrm{hrs}$. in both the groups.

Our study found the incidence of nausea, retching and vomiting during 2 - 48 hours' period was $10 \%, 6 \%$ and $6 \%$ respectively among $\mathrm{P}$ Group and $6 \%, 2 \%$ and $2 \%$ respectively among PD Group. Park J W et al 20 found the incidence of nausea and vomiting as $2.4 \%$ and $0 \%$ respectively in palonosetron group and $4.7 \%$ and $2.3 \%$ in the palonosetrondexamethasone group during 2 - $24 \mathrm{hrs}$. Bala I et al ${ }^{20}$ found the incidence of nausea and vomiting as $35.7 \%$ and $23.8 \%$ respectively in the palonosetron group and $14.3 \%$ and $7.1 \%$ respectively in the palonosetron-dexamethasone group during $2-24 \mathrm{hrs}$. It was $4.8 \%$ and $0 \%$ respectively in palonosetron group and none in palonosetrondexamethasone group during 24 - 48 hrs. However, Ghosh S et $\mathrm{al}^{24}$ reported the incidence of nausea and retching was 5 patients $(16.66 \%)$ in palonosetron group and 4 patients 
(13.33\%) in palonosetron-dexamethasone group during 24 48 hrs. postoperatively. None of the patients had any vomiting episodes at any period of time postoperatively.

Park J W et al ${ }^{20}$ reported $90.2 \%$ and $86 \%$ of patients in palonosetron group and palonosetron-dexamethasone group respectively had complete response for PONV over 24 hours. These results were close to our study having observed in $70 \%$ and $86 \%$ in P and PD Group. However, the complete response was lesser in the palonosetron group in comparison to the study conducted by Park J W et al, ${ }^{20}$ Ghosh S et al ${ }^{24}$ reported the number of complete response was $83 \%$ in palonosetron group and $86.66 \%$ in palonosetrondexamethasone group over the period of $48 \mathrm{hrs}$. However, the complete response in our study was $70 \%$ and $86 \%$ during first 0 - 2 hrs. and $90 \%$ and $94 \%$ during 0 - 48 hours' periods among $\mathrm{P}$ and $\mathrm{PD}$ Group respectively $(\mathrm{P}=0.357)$. Bala et al ${ }^{19}$ also found a complete response of $59.5 \%$ and $85.7 \%$ among $\mathrm{P}$ and PD Group during 0 - 2 hrs. and $64.3 \%$ and $85.7 \%$ among $P$ and PD Group during 2 - 24 hrs.

The incidence of rescue antiemetic used in our study was significantly reduced in PD Group than in P Group during the first 0 - 2 hours' period (14\% vs. $30 \%)(P=0.045)$. However, Ghosh $\mathrm{S}$ et $\mathrm{al}^{24}$ reported that none of their patients required rescue antiemetics. Bala I et al ${ }^{19}$ found the requirement of rescue antiemetic was $9(21.4 \%)$ vs $4(9.6 \%)$ in palonosetron group and palonosetron-dexamethasone group during $0-2$ hrs. postoperatively, $13(31.0 \%)$ vs 5 (11.9\%) in palonosetron group and palonosetron-dexamethasone group respectively during 2 - $24 \mathrm{hrs}$. and 18 (42.9\%) vs 6 (14.3\%) in palonosetron group and palonosetron-dexamethasone group respectively during 0 - $24 \mathrm{hrs}$.

The reason of more effective control of PONV and longlasting effects by palonosetron-dexamethasone combination can partly be explained by unique pharmacodynamic characteristic possessed by palonosetron due to its high affinity and selectivity for 5-HT3 receptors binding (allosteric) orthosteric site and dexamethasone, a long-acting glucocorticoid, an effective antiemetic in cancer chemotherapy patients and found to have a prophylactic effect on PONV in adults undergoing laparoscopic surgeries. $7,14,25$

During study, few patients from both groups complained of non-specific symptoms, viz. headache and dizziness which was also reported by Bala I et al ${ }^{19}$ and Ghosh S et al.24 Clinically, serious adverse events did not occur during our study period.

The study was not without its own limitation. The complete absence of post-operative nausea and vomiting could not be achieved because of multifactorial pathways of PONV, independent risk factors like preoperative history of PONV, 26,27 motion sickness and some degree of subjectivity which is inevitable in the assessment of patient satisfaction profile. The uses of inhalational agents, nitrous oxide, tramadol, neostigmine and glycopyrrolate 27,28 as a part of standard anaesthesia practice attributed the nausea and vomiting during postoperative periods.

\section{CONCLUSION}

It may be concluded that combination prophylaxis of intravenous palonosetron $0.075 \mathrm{mg}$ and dexamethasone $8 \mathrm{mg}$ is more effective than palonosetron in the prevention of postoperative nausea and vomiting in patients undergoing laparoscopic cholecystectomy under general anaesthesia without any major adverse effects. Further, studies are required to achieve complete absence of PONV by attempting to reduce attributable risk factors to minimum.

\section{REFERENCES}

[1] Naguib M, el Bakry AK, Khoshim MH, et al. Prophylactic antiemetic therapy with ondansetron, tropisetron, granisetron and metoclopramide in patient undergoing laparoscopic cholecystectomy: a randomized doubleblind comparison with placebo. Can J Anaesth 1996;43(3):226-31.

[2] Fredman B, Jedeikin R, Olsfanger D, et al. Residual pneumoperitoneum: a cause of postoperative pain after laparoscopic cholecystectomy. Anesth Analg 1994;79(1):152-4.

[3] Litomi T, Totumi S, Kondo A, et al. Incidence of nausea and vomiting after cholecystectomy performed via laparotomy or laparoscopy. Masui 1995;44(12):162731.

[4] Fuji Y. The utility of antiemetics in the prevention and treatment of postoperative nausea and vomiting in patients scheduled for laparoscopic cholecystectomy. Curr Pharma Des 2005;11(24):3173-83.

[5] Apfel CC, Korttila K, Abdalla M, et al. A factorial trial of six interventions for the prevention of postoperative nausea and vomiting. N Engl J Med 2004;350(24):244151.

[6] Gan TJ. Selective serotonin 5-HT3 receptor antagonists for postoperative nausea and vomiting: are they all same. CNS Drugs 2005;19(3):225-38.

[7] Rojas C, Stathis M, Thomas AG, et al. Palonosetron exhibits unique molecular interactions with the 5-HT3 receptor. Anesth Analg 2008;107(2):469-78.

[8] Stoltz R, Parisi S, Shah A, et al. Pharmacokinetic, metabolism and excretion of intravenous [14C] palonosetron in healthy human volunteers. Biopharm Drug Dispos 2004;25(8):329-37.

[9] Aapro MS, Macciocchi A, Gridelli C. Palonosetron improves prevention of chemotherapy induced nausea and vomiting in elderly patients. J Support Oncol 2005;3(5):369-74.

[10] Machatuta NA, Paech MJ. Management of postoperative nausea and vomiting: focus on palonosetron. Ther Clin Risk Manag 2009;5(1):21-34.

[11] Bicer C, Aksu R, Ulgey A, et al. Different doses of palonosetron for the prevention of postoperative nausea and vomiting in children undergoing strabismus surgery. Drugs R D 2011;11(1):29-36.

[12] Ho CM, Ho ST, Wang JJ, et al. Dexamethasone has a central antiemetic mechanism in decerebrated cats. Anesth Analg 2004;99(3):734-9.

[13] Loannidis JP, Hesketh PJ, Lau J. Contribution of dexamethasone to control of chemotherapy induced nausea and vomiting: a meta-analysis of randomized evidence. J Clin Oncol 2000;18(19):3409-22.

[14] Wang JJ, Ho ST, Liu YH, et al. Dexamethasone reduces nausea and vomiting after laparoscopic cholecystectomy. Br J Anaesth 1999;83(5):772-5. 
[15] Stanbury R, Graham E. Systemic corticosteroid therapy side effects and their management. Br J Ophthalmol 1998;82(6):704-8.

[16] Wang JJ, Ho ST, Tzeng JI, et al. The effect of timing of dexamethasone administration on its efficacy as a prophylactic antiemetic for postoperative nausea and vomiting. Anesth Analg 2000;91(1):136-9.

[17] Henzi I, Walder B, Tramer MR. Dexamethasone for the prevention of postoperative nausea and vomiting: a qualitative systematic review. Anesth Analg 2000;90(1):186-94.

[18] Sharma AN, Shankaranarayana P. Postoperative nausea and vomiting: palonosetron with dexamethasone vs. ondansetron with dexamethasone in laparoscopic hysterectomies. Oman Med J 2015;30(4):252-6.

[19] Bala I, Bharti N, Murugesan S, et al. Comparison of palonosetron with palonosetron-dexamethasone combination for prevention of postoperative nausea and vomiting in patients undergoing laparoscopic cholecystectomy. Minerva Anestesiol 2014;80(7):77984.

[20] Park JW, Jun JW, Lim YH, et al. The comparative study to evaluate the effect of palonosetron monotherapy versus palonosetron with dexamethasone combination therapy for the prevention of postoperative nausea and vomiting. Korean J Anesthesiol 2012;63(4):334-9.

[21] Bhattacharjee DP, Dawn S, Nayak S, et al. A comparative study between palonosetron and granisetron to prevent postoperative nausea and vomiting after laparoscopic cholecystectomy. J Anaesthesiol Clin Pharmacol 2010;26(4):480-3.
[22] Park SK, Cho EJ. A randomized double blind trial of palonosetron compared with ondansetron in preventing postoperative nausea and vomiting after gynaecological laparoscopic surgery. J Int Med Res 2011;39(2):399407.

[23] Erhan Y, Erhan E, Aydede H, et al. Ondansetron, granisetron and dexamethasone compared for the prevention of postoperative nausea and vomiting in patient undergoing laparoscopic cholecystectomy: a randomized placebo-controlled. Surg Endosc 2008;22(6):1487-92.

[24] Ghosh S, Pal A, Acharya A, et al. Palonosetron and palonosetron plus dexamethasone to prevent nausea and vomiting in patients undergoing laparoscopic cholecystectomy: a prospective randomised double blind comparative study. Anaesthesia Essays Res 2011;5(2):134-7.

[25] Aapro MS, Albert DS. Dexamethasone as an antiemetic in patients treated with cisplatin. $\mathrm{N}$ Engl J Med 1981;305(9):520.

[26] Mraovic B, Jurioic T, Kogler-Majeric V, et al. Intraperitoneal bupivacaine for analgesia after laparoscopic cholecystectomy. Acta Anaesthesia Scand 1997;41(2):193-6.

[27] Cohen MM, Duncan PG, DeBoer DP, et al. The postoperative interview: assessing risk factors for nausea and vomiting. Anesth Analg 1994;78(1):7-16.

[28] Watcha MF, White PF. Postoperative nausea and vomiting, its aetiology, treatment and prevention. Anaesthesiology 1992;77(1):162-84. 